\title{
CORRELATION BETWEEN DHEA-S LEVELS AND MARKERS OF BONE TURNOVER IN HYPOTHALAMIC AMENORRHEA
}

Authors: ANTONIO MANCINI ${ }^{1}$, DANIELA ROMUALDI ${ }^{2}$, SEBASTIANO RAIMONDO ${ }^{1}$, CHRISTIAN DI FLORIO ${ }^{2}$, CHANTAL DI SEGNI ${ }^{1}$, CARMINE BRUNO ${ }^{1}$, ROSANNA APA2 ${ }^{2}$ ANTONIO LANZONE ${ }^{2}$

Affiliations: 1.OPERATIVE UNIT OF ENDOCRINOLOGY, CATHOLIC UNIVERSITY OF THE SACRED HEART, ROME, ITALY

2. DEPT. OF OBSTETRICS AND GYNECOLOGY, CATHOLIC UNIVERSITY OF THE SACRED HEART, ROME, ITALY

\section{OBJECTIVES}

It is known that functional hypothalamic amenorrhea is associated with low bone turnover due to low gonadal homone levels. Estrogens are critical for activation of bone remodelling units, suppression of bone reabsorption, increase of 1$25(\mathrm{OH})$ Vitamin D receptors expression. Other mechanisms could be operative, including improper diet and unbalanced exercise; however the physiopathology of such a condition is not entirely known. In order to evaluate the correlation between pituitary, gonadal and adrenal hormones with markers of bone metabolism, we have studied a group of 21 female patients with a history of secondary amenorrhea, lasting at least six months.

\section{METHODS}

They were aged 19-35 ys, with a BMI range 17.5-19.5 $\mathrm{kg} / \mathrm{mq}$. Bone mineral density (BMD) was determined by DXA scan at lumbar spine and neck of the right hip femur. The following parameters were evaluated in a blood morning sample: $\mathrm{FSH}, \mathrm{LH}$, estradiol, ACTH, DHEAS, osteocalcin, bone alkaline phosphatase, beta-cross laps, Vitamin D and PTH. Hormones were assayed by CMIA or CLIA method; osteocalcin and beta-crosslaps by electrochemiluminesce.
Fig.1

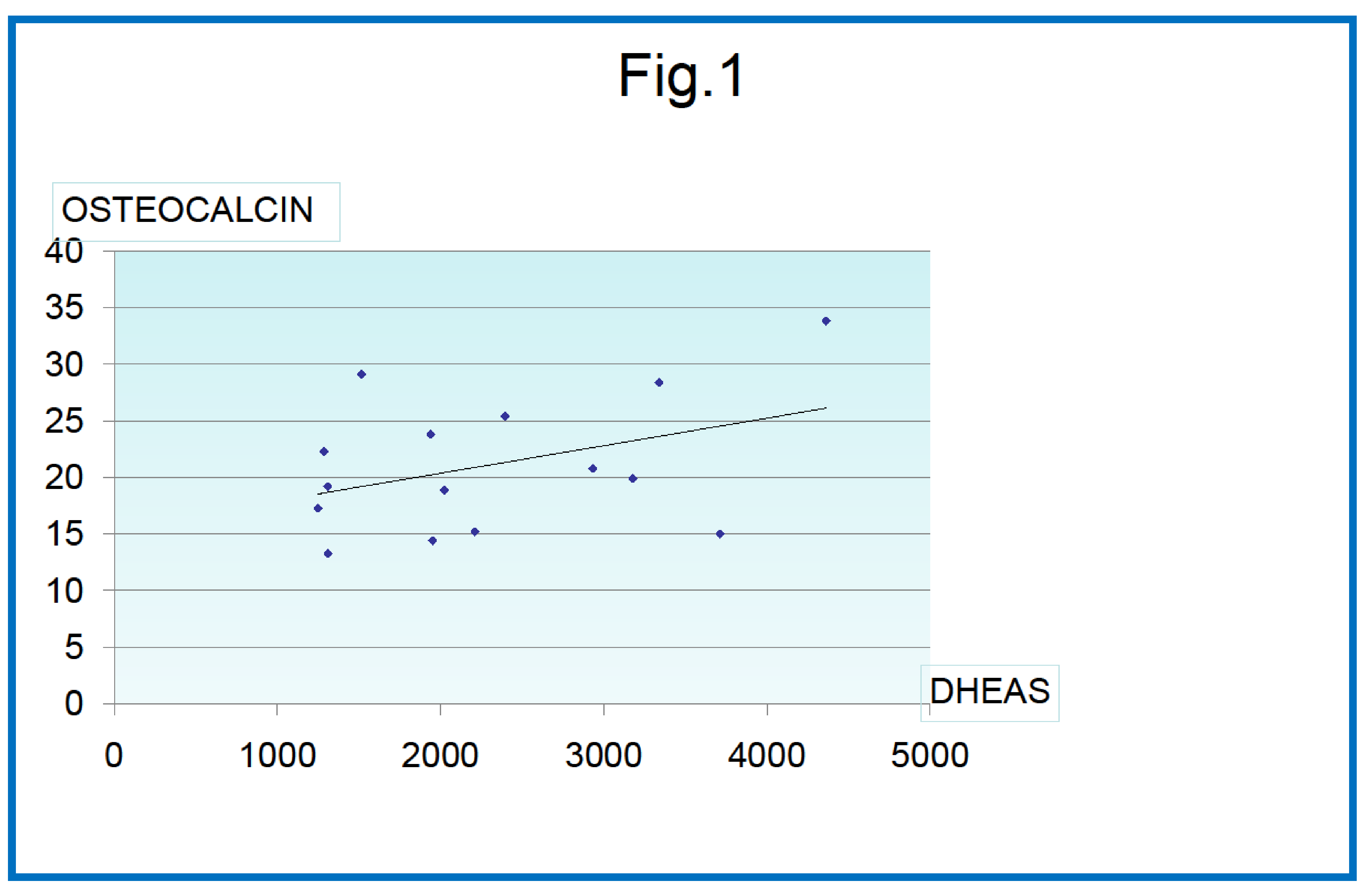

\section{RESULTS}

DXA evaluation showed a significant reduction in BMD (osteopenia or osteoporosis) in 8 patients (T score at lumbar spine from -1.1 to -2.9 ). Mean \pm SEM hormone values are reported in table 1 . Mean $25(\mathrm{OH})$-Vitamin D were $28.8 \pm 1.56 \mathrm{ng} / \mathrm{ml}$ (with 13 patients with values in the range of Vitamina $D$ deficiency); DHEAS, on the contrary, were in the normal range $(2460.4 \pm 232$ $\mathrm{ng} / \mathrm{ml})$ and showed a significant direct correlation with osteocalcin $(p<0.05)$ (Fig. 1).

\begin{tabular}{|c|c|c|}
\hline & Mean \pm SEM & NORMAL RANGE \\
\hline FSH & $5,38 \pm 0,34$ & $2,5-11 \mathrm{mU} / \mathrm{ml}$ \\
\hline LH & $2,24 \pm 0,49$ & $2,5-15 \mathrm{mU} / \mathrm{ml}$ \\
\hline Estradiolo & $26,16 \pm 4,9$ & $21-251 \mathrm{pg} / \mathrm{ml}$ \\
\hline АCTH & $17,42 \pm 1,75$ & $10-55 \mathrm{pg} / \mathrm{ml}$ \\
\hline DHEAS & $2460 \pm 232$ & $800-3500 \mathrm{ng} / \mathrm{ml}$ \\
\hline Osteocalcin & $20,82 \pm 1,81$ & $10-45 \mathrm{ng} / \mathrm{ml}$ \\
\hline $\begin{array}{l}\text { Bone Alkaline } \\
\text { Phosphatase }\end{array}$ & $0,32 \pm 0.02$ & $5.5-25 \mu \mathrm{g} / \mathrm{L}$ \\
\hline Beta Cross Laps & $0,54 \pm 0.04$ & $0,2-1 \mathrm{ng} / \mathrm{ml}$ \\
\hline Vitamin D & $28,80 \pm 1,56$ & $31-100 \mathrm{ng} / \mathrm{ml}$ \\
\hline PTH & $33,32 \pm 4$ & $10-65 \mathrm{pg} / \mathrm{ml}$ \\
\hline
\end{tabular}

